\title{
The effect on taxpayers of new tax legislation regarding foreign exchange transactions
}

\section{R Oberholzer}

Department of Taxation, University of Pretoria

\section{JS Wilcocks}

School of Applied Accountancy, University of South Africa

Received: January 2004

SAJAR

Revised: June 2004

Vol 18 No. 1

Accepted: June 2004

Numerous problems have been encountered with the practical application of the new taxation legislation relating to foreign currency transactions. The purpose of this paper is to analyse the amendments relating to foreign exchange transactions and to illustrate, by using examples, the far reaching effect of these amendments on the taxpayer, as well as the effect on the financial statements for accounting purposes. The paper concentrates on the amendments to sections 25D and 24I (with specific reference to section 24I(11)) contained in the Second Revenue Laws Amendment Act (Act 74 of 2002) (promulgated on 13 December 2002) and the Revenue Laws Amendment Act (Act 45 of 2003) (promulgated on 22 December 2003). The paper continues to also illustrate the interaction and the effect of the Eighth Schedule on sections $25 \mathrm{D}$ and $24 \mathrm{I}$.

\section{KEY WORDS}

Average exchange rate, Ruling exchange rate (spot rate), Foreign currency,

Telegraphic transfer buying rate, Permanent establishment, Temporary difference

\section{ACKNOWLEDGEMENTS}

An earlier version of the paper was presented at the 2003 South African Accounting Association Central Regional Conference. We thank Professor M.J. Nieuwoudt, our colleagues and two anonymous reviewers for their comments on earlier drafts. 


\section{INTRODUCTION}

The Director-General: National Treasury, Lesetja Kganyago states in his foreword of the 2004 budget that the Republic has undergone a remarkable transformation since 1994. As we celebrate ten years of freedom this year, South Africans have much to be proud of. A favorable environment for trade and industrial development are established features of the South African economy (National Treasury 2004:iii)

Global economic growth has strengthened over the past year and the outlook for 2004 is encouraging (National Treasury 2004:6). The Budget Review provides interesting statistics on the Republic's performance on the world stage (National Treasury 2004:29) for example, the R28.3 billion of net capital inflows in the second quarter of 2003 was the highest ever recorded quarterly net inflow of capital into the Republic, comprising mainly net portfolio investment of R22.6 billion. Foreign direct investment into the Republic increased from R0.6 billion in the second quarter to R1.8 billion in the third quarter of 2003. A similar pattern applies for the Republic's assets in the rest of the world. Of particular significance is the growth in the Republic's interests in the African continent.

On the back of robust domestic demand, the firm currency and rising oil volumes, imports grew strongly in 2003, recording 8.3 percent growth compared with more modest growth of 3.1 percent in 2002. Since 1994, imports have grown at an annual average rate of 6.7 percent compared to 3.6 percent in the period 1984 to 1993 (National Treasury 2004:34). The exchange rate has recovered strongly from the weakness in late 2001. The Rand performed well against the weakening dollar through 2003 and also advanced against the currencies of the Republic's major trading partners (National Treasury 2004:35).

The involvement of South African firms in transactions involving foreign currency is not limited to multi-nationals. Indeed, many firms acquire stock and capital goods from overseas suppliers or export these items. These firms also enter into forward exchange contracts (FEC's) and foreign currency option contracts (FCOC's) in order to limit foreign exchange risk. In addition, these firms may also obtain loan finance from overseas sources. Foreign exchange transactions and foreign exchang positions held, have an effect on the determination of taxable income (SAICA 2003:70) 
In 2001 the Republic changed from a source- to a residence-based taxation basis, resulting in the taxation of a resident on his or her worldwide income. This resulted in the introduction of section 25D and major changes to section 24I in order to facilitate the incorporation of foreign sourced income into a taxpayer's taxable income.

For the fourth time in a row, tax year 2004 produced more than one Taxation Laws Amendment Act. The Revenue Laws Amendment Act 2003 ('Act 45 of 2003’) was promulgated on 22 December 2003.

This paper investigates the amendments to sections 25D and section 24I, with specific reference to section 24I(11), of the Income Tax Act 58 of 1962 (the Act), which relates to foreign exchange transactions and the implications thereof on taxpayers. Legislation passed until 31 December 2003 was taken into account for purposes of the study. The new legislation, as will be illustrated, might lead to different treatments for accounting and tax purposes impacting all taxpayers dealing in foreign exchange activities.

\section{RESEARCH PROBLEM AND OBJECTIVE}

Numerous problems have been encountered with the practical application of the new taxation legislation relating to foreign currency transactions. The purpose of this paper is to analyse the amendments relating to foreign exchange transactions and to illustrate, by using examples, the far-reaching effect of these amendments on the taxpayer, as well as the effect on the financial statements for accounting purposes. The paper concentrates on the amendments to sections 25D and 24I (with specific reference to section 24I(11)) contained in the Second Revenue Laws Amendment Act 74 of 2002 ('Act 74 of 2002')(promulgated on 13 December 2002) and Act 45 of 2003. The paper continues to also illustrate the interaction and the effect of the Eighth Schedule on the sections mentioned.

\section{RESEARCH METHOD}

The research methods followed include the following:

- A literature review was performed in order to analyse the amendments to sections 25D and 24I in order to fully comprehend the intention and meaning thereof. It should be noted that content analysis was used to analyse the amendments to the legislation.

- Discussions with South African Revenue Service (SARS) officials at the Law Interpreters division (Brooklyn, Pretoria) on 9 April and 8 May 2003, in order to 
establish the view of the SARS regarding the amendments contained in Act 74 of 2002.

- Examples were used to better illustrate the effect of the amendments contained in Act 74 of 2002 and Act 45 of 2003 for tax and accounting purposes. All historic exchange rates used in the examples were obtained from www.xrates.com (accessed 7 April 2004). Future exchange rates were based on estimates.

- A detailed analysis of the term 'average exchange rate' was performed using current legislation. In addition this analysis was compared with Australian legislation.

\section{SECTION 25D}

\section{Scope}

Section 25D was introduced into the Income Tax Act in 2000, in order to provide for the determination of the taxable income or loss of any resident that is derived from a foreign source in the foreign currency of the country from which the income is derived. (Department of Finance, Explanatory Memorandum on the Revenue Laws Amendment Bill 2000:25).

Once the amount of the taxable income was determined, that amount had to be converted on the last day of the year of assessment to the currency of the Republic at the ruling exchange rate on that date. The Commissioner could however approve another exchange rate, taking into account the ruling exchange rates during the year of assessment.

This section, when it was introduced into the Act, did not make reference to any income received and expenditure incurred, but only to the taxable income derived by any resident from a source outside the Republic.

Section 25D was amended by the Second Revenue Laws Amendment Act 60 of 2001 ('Act 60 of 2001') and this Act provided that taxable income from income attributable to a permanent establishment of a resident outside the Republic, had to be determined in the relevant currency of the country in which that permanent establishment was situated, if the financial records of that permanent establishmen were kept in that currency. The amount of the taxable income so determined, had to be converted on the last day of the relevant year of assessment to the currency of the Republic at the ruling exchange rate on the last day of that year of assessment. The Commissioner could however approve another exchange rate taking into account the ruling exchange rates during that year of assessment (Department of Finance, 
Explanatory Memorandum on the Second Revenue Laws Amendment Bill 2001 ('Explanatory Memorandum 2001'):31).

Where income was not attributable to a foreign permanent establishment in the circumstance as described above, the taxable income had to be determined in the currency of the Republic (Department of Finance, Explanatory Memorandum 2001:31). Any income received or accrued and any expenses incurred in these instances, had to be determined separately in Rand, by translating the relevant income received or accrued or the expenditure incurred in foreign currency to Rand by applying the ruling exchange rate at that time when the income was received or accrued or when that expense was incurred. Effectively, all currency gains and losses were, therefore, picked up in the calculation and included in taxable income (Department of Finance, Explanatory Memorandum on the Revenue Laws Amendment Bill 2002 ('Explanatory Memorandum 2002’):12).

The term 'permanent establishment' is defined in section 1 of the Act with reference to the definition in article 5 of the Model Tax Convention on Income and on Capital (29 April 2002) of the Organisation for Economic Co-operation and Development. In brief the Model Tax Convention refers to a fixed place of business through which the business of an enterprise is wholly or partly carried on and specifically includes a place of management, a branch, an office, a factory, a workshop, a mine, an oil or gas well, a quarry or any other place of extraction of natural resources and a building site or construction or installation project that lasts more than 12 months. An enterprise will not be a permanent establishment merely because it carries on business in that State through a broker or independent agent, it uses facilities solely for purposes of storage, display or delivery of goods or the maintenance of such goods for purposes of display, delivery or storage or for purpose of processing by another enterprise. A fixed place of business will not be a permanent establishment if used solely for the purpose of purchasing goods or merchandise or for collecting information, or for the carrying on for the enterprise of any other activity of a preparatory or auxiliary character. It is important to note that the fact that a resident company is controlled or controls a company that is resident in another contracting state, shall not of itself imply that either company is a permanent establishment of the other.

\section{Changes contained in Act $\mathbf{7 4}$ of 2002}

With the changes to the Act contained in Act 74 of 2002, effective for years of assessment commencing on or after 13 December 2002, the scope of this section was potentially broadened extensively.

Section 25D as amended by Act 74 of 2002, reads as follows (own emphasis): 
"25D. Determination of taxable income in foreign currency. - The amount of any taxable income derived by a person during any year of assessment from amounts received by or accrued to, or expenditure incurred by, that person which are denominated in any currency other than currency of the Republic, shall be determined-

(a) in that currency; or

(b) where that income is attributable to a permanent establishment of that person outside the Republic, in the currency used by that permanent establishment for purposes of financial reporting,

and the amount so determined shall be translated to the currency of the Republic by applying the average exchange rate for that year of assessment."

Although the heading of the section still refers to "Determination of taxable income in foreign currency" the words "from a source outside the Republic" were repealed. This section potentially now refers to more than just taxable income from a foreign trade.

The first part of the section refers to the amount of any taxable income derived by a person during any year of assessment from amounts received by or accrued to, or expenditure incurred by that person, which are denominated in any foreign currency. The words in bold were not previously included in the legislation. "Taxable income" is defined in section 1 of the Act and means the aggregate of the amount remaining after deducting from the income of any person all the amounts allowed under Part I of Chapter II to be deducted from or set off against such income.

No reference is made to taxable income from a foreign source. Based on content analysis it appears that if an amount is received by or accrued to, or an expense is incurred by a taxpayer in a foreign currency, that specific amount must be translated in determining the taxable income using the average exchange rate.

\section{Relevance of the heading of section 25D}

There is no clear-cut answer to the question whether any relevance must be given to the heading of the amended section 25D. The heading: "Determination of taxable income in foreign currency”, refers only to taxable income in a foreign currency (therefore taxable income from a foreign trade) and not to income or expenditure in a foreign currency (therefore individual foreign currency transactions).

Headings and sub-headings are considered portions of the enactment, available for consultation, too, in the event of ambiguity or obscurity (Hahlo \& Kahn,1973:198 \& Steyn, 1981:148). In Turffontein Estates Ltd v Mining Commissioner, Johannesburg 
1917 AD 419 at 431 Innes CJ stated that a heading is incorporated into an Act and continued "we are therefore fully entitled to refer to it for the elucidation of any clause to which it relates. It is impossible to lay down any general rule as to the weight, which should be attached to such headings. The object in each case is to ascertain the intention of the Legislature, and the heading is an element in the process".

Steyn (1981:148) queries however whether a heading on its own will be relevant when one or more stipulation has ambiguous meanings. Steyn again refers to judge Innes CJ's judgement in Turffontein Estates Ltd v Mining Commissioner at 431: "Where the intention of the lawgiver as expressed in any particular clause is quite clear, then it cannot be overridden by the words of the heading. But where the intention is doubtful, whether the doubt arises from ambiguity in the section itself or from other considerations, then the heading may become of importance. The weight to be given to it must necessarily vary with the circumstances of each case.”

Botha (1998:88-89) states "headings to sections may be regarded as a preamble to a section. Within the framework of the contextual approach all factors, including headings, should be considered to determine the purpose of the legislation. In the past the courts held the textual viewpoint that headings may be used by the courts to establish the purpose of the legislation only when the rest of the provision is not clear. (Chotabhai v Union Government 1911 AD 24). In Mpangele v Botha 19823 SA 632 (C), however the value of headings in the interpretation of legislation was questioned”.

From the above it seems that the importance of the heading of section 25D and the effect it has on interpretation is questionable.

\section{Implications of the changes in legislation}

The proposed changes to section 25D contained in Act 74 of 2002 will have an adverse effect, specifically on the tax and accounting treatments. Taxpayers buying fixed assets from an overseas supplier (where the price is denominated in a foreign currency) will have to calculate depreciation on the value of the asset translated to Rand at the spot rate and wear and tear on the value of the asset translated to Rand at the average exchange rate. This could lead to exempt temporary differences (commonly referred to as permanent differences) in terms of paragraph 15 or paragraph 24 of 'The Statement of Generally Accepted Accounting Practice on Income Taxes’ (IAS 12) (SAICA Handbook: accessed 8 April 2004). An example will best illustrate the effect, but to clarify the accounting treatment, the basic accounting treatment of exchange differences will first be discussed. 


\section{Accounting treatment of exchange differences}

According to AC 112 paragraph .09 - .11 (SAICA Handbook: accessed 8 April 2004) a foreign currency transaction (including transactions arising when an enterprise buys or sells goods or services of which the price is denominated in foreign currency) should be recorded, on initial recognition in the reporting currency, by applying to the foreign currency amount the exchange rate between the reporting currency and the foreign currency at the date of the transaction. The exchange rate at the date of the transaction is often referred to as the spot rate.

Paragraph .16 in AC 112 (SAICA Handbook: accessed 8 April 2004) determines that exchange differences arising on the settlement of monetary items or on reporting an enterprise's monetary items at rates different from those at which the transaction was initially recorded during the period, or reported in previous financial statements, should be recognised as income or expenses in the period in which they arise.

The only time when an exchange difference can be included in the carrying amount of the related asset, will be if the exchange differences are a result of a severe devaluation or depreciation of a currency against which there is no practical means of hedging which affects liabilities that cannot be settled and arise directly on the recent acquisition of an asset invoiced in a foreign currency (AC 112 par .22) (SAICA Handbook: accessed 8 April 2004).

\section{Example}

Company A (with a February year end) frequently imports assets from America. On 1 March 2003 the company buys workshop equipment costing \$50 000. The spot rate on this day is $\$ 1.00=\mathrm{R} 6.625$. The write off period in terms of Practice Note 19 is 5 years for workshop equipment and the accounting policy is to depreciate equipment over 5 years on the straight-line method. The average exchange rate for the year of assessment ending 29 February 2004 is $\$ 1.00=\mathrm{R} 7.284$

\section{Implications of the transaction for the year ending 29 February 2004}

\section{Tax consequences:}

For tax purposes according to section 25D (based on content analysis) where expenditure is incurred by a person in a foreign currency the amount shall be translated to the currency of the Republic applying the average exchange rate: $\$ 50000$ x R7.284 = R364 200

Wear and tear deduction for the year will amount to R364 200 / 5 


\section{Accounting treatment:}

For accounting purposes the initial recognition of the equipment will be calculated by applying to the foreign currency amount the spot rate on the date of the transaction:

$\$ 50000$ x R6.625 = R331 250

Depreciation charge for the year will amount to R331 250 / 5

From the above it is clear that although the same write-off periods for accounting and tax treatment are selected a difference between depreciation and wear and tear deductions will arise, due to the difference in the value at which the asset is recorded.

The difference will consist of an exempt temporary difference (commonly referred to as permanent differences), which will be the difference in the initial value at which the item is recorded for taxation and accounting purposes. The value of this difference will be R32 950 (R364 200 (taxation value) - R331 250 (accounting value)) (The Statement of Generally Accepted Accounting Practice on Income Taxes - IAS 12 paragraph 24 - SAICA Handbook: accessed 8 April 2004). The difference has to be taken into account in the tax rate reconciliation in the financial statements.

As section 25D refers to expenditure incurred, taxpayers buying trading stock from an overseas supplier or incurring any other section 11(a) tax-deductible expense in foreign currency, might also encounter the above problem as exempt temporary differences might arise as a result of the difference between the accounting and tax treatment of the expense.

\section{The view of the South African Revenue Service}

According to the Explanatory Memorandum 2002 (Department of Finance:8) the new legislation proposed that for purposes of determining the amount of income derived from foreign sources, the application of the ruling exchange rate must be replaced by an average exchange rate for the relevant year of assessment of the resident. If an average exchange rate for a year is used, all income received by or accrued to a resident from a foreign source and all expenditure incurred will be determined in the relevant foreign currency before the amount of taxable income is translated into Rand.

In this regard, it is proposed that where the income -

- $\quad$ is attributable to a permanent establishment of the resident, the calculation of the amount of taxable income must be done in the currency used by the permanent establishment for purposes of financial reporting; or 
- $\quad$ is not attributable to a permanent establishment, the calculation must be done in the currency in which the relevant income or expenditure is denominated.

The amount of taxable income so determined in the foreign currency, must then be translated to Rand by using the average exchange rate for the relevant year of assessment. By using the average exchange rate for a year of assessment, most currency gains or losses that arise during the year of assessment are diminished and some are not subject to tax (Department of Finance, Explanatory Memorandum 2002:8).

From the above it is clear that the intention of the SARS was to change only the rate from the ruling exchange rate on transaction date to the average exchange rate of the applicable year of assessment when a taxpayer is converting taxable income attributable from a foreign source and not if a taxpayer converts individual foreign currency transactions (the underlying item will therefore still be translated by using the spot rate, unless taxable income is received from a foreign source). Discussions with SARS officials at the Law Interpreters Division (Brooklyn, Pretoria) on 9 April and 8 May 2003, confirmed this as their intention. The fact that Practice Note 4, issued by the South African Revenue Service on 8 March 1999, dealing with the treatment of foreign exchange transactions in terms of section 24I, has not been withdrawn or amended can also be interpreted as a confirmation of the above stance. This Practice Note translates all underlying items (the expenses incurred) in the examples used in Appendix C, by using the spot rate.

It appears that SARS's view differs from the interpretation based on content analysis. Although SARS's view is important, Meyerowitz (2002:3.14) mentions that the governing rule of interpretation is in general to endeavor to ascertain the intention of the law maker from a study of the provisions in question, and what really matters is the intention of the Legislature as expressed in the language of the Act. If therefore, the language used by the Legislature is both clear and intended, it cannot be departed from. If the intention of the Legislature is not expressed, there is a casus omissus, which cannot be supplied by the courts whose sole duty is to construe the Act as it stands. According to Webster's Revised Unabridged Dictionary (accessed 8 April 2004) casus omissus means, a case not provided for by the statute.

In Stafford v Special Investigating Unit 19984 All SA 543 (E) at 553 Judge Leach J states "...... court cannot supplement a statute by providing what it surmises the legislature omitted. The court therefore must give effect to what the Act says and not to what it thinks it ought to have said".

Meyerowitz (2002:3.25) stresses that in case of doubt the contra fiscum rule must be invoked. This means that a doubtful (ambiguous) provision in a taxation statute must be construed against the larger imposition, or benefit of the doubt must be given to 
the person sought to be charged. We are of the opinion that a taxpayer (currently) will be able to defend the use of either the spot or the average exchange rate.

\section{Changes contained in Act $\mathbf{4 5}$ of 2003}

Section 25D as amended by Act 45 of 2003, reads as follows:

“25D. Determination of taxable income in foreign currency. -

(1) Unless expressly otherwise provided in this Act, any amount derived by a person during any year of assessment from amounts received by or accrued to, or in respect of expenditure incurred by, that person in any currency other than the currency of the Republic, shall be determined -

(a) where the amounts so received, accrued or incurred are attributable to a permanent establishment of that person outside the Republic, in the currency used by that permanent establishment for purpose of financial reporting (other than the currency of any country in the common monetary area); or

(b) in any other case, in the currency in which the amounts so received or accrued or the expenditure so incurred is denominated.

(2) Unless expressly otherwise provided in this Act, the amount determined in terms of this Act in any currency other than the currency of the Republic, must be translated to the currency of the Republic by applying the average exchange rate for the relevant year of assessment."

Section 25D provides the general rule for purposes of determining taxable income when the initial starting point of the calculation begins in foreign currency. Taxpayers first "determine" the calculation in the applicable foreign currency and then "translate" the calculation to Rand at the average exchange rate for the year at issue (Department of Finance, Explanatory Memorandum on the Revenue Laws Amendment Bill 2003 ('Explanatory Memorandum 2003’):62).

The amendment to subsection 1 clarifies that amounts received, accrued or incurred in foreign currency are initially “determined” in:

- the financial reporting currency utilised by a foreign permanent establishment if amounts received, accrued or incurred are attributable to a permanent establishment of the person outside the Republic; or

- the actual currency of the amounts received, accrued or incurred in all other cases (i.e., the amounts are not attributable to a foreign permanent establishment) (Department of Finance, Explanatory Memorandum 2003:62). 
The amendment also clarifies that the general rules provided above apply "unless expressly otherwise provided" in this Act. Hence, the provisions of section 9G and paragraph 43 of the Eight Schedule generally take precedence over this provision (Department of Finance, Explanatory Memorandum 2003:62).

The amendment to subsection 2 clarifies that once an amount has been determined under subsection 1 (or any other provision of the Income Tax Act), the determined amount must be translated into Rand by applying the relevant average exchange rate for the tax year of the determination (Department of Finance, Explanatory Memorandum 2003:62).

The following example, adapted from the Explanatory Memorandum 2003, illustrates the application of section 25D (Mitchell \& Mitchell 2004:127).

\section{Example}

A South African Company imports and then exports trading stock in pounds solely from its South African location. The trading stock costs $£ 100$ and is sold for $£ 120$. The purchase and sale arises within the same year of assessment. The average exchange rate for the year is $£ 1=\mathrm{R} 10$.

Under section 25D(1), the South African Company first determines a taxable income in pounds, resulting in a taxable income of $£ 20(£ 120-£ 100)$.

Under section $25 \mathrm{D}(2)$, the $£ 20$ taxable income is then translated to Rand at R10 to the $£ 1$ (being the average exchange rate for the year), resulting in a taxable income of R200 ( $£ 20 \times$ R10).

Again it is not clear whether the wording of the section only refers to taxable income from a foreign trade (as indicated in the example provided in the Explanatory Memorandum) or whether this section also refers to income received or expenditure incurred by a taxpayer in a foreign currency (following the content analysis of the section). The far-reaching effect as discussed in the previous example will remain unaltered if the content analysis takes preference.

\section{Determination of the average exchange rate}

\section{Proposed calculation of the average exchange rate}

The calculation of the average exchange rate can also be a very complex issue. 'Average exchange rate' is defined in section 1 of the Act (inserted by Act 74 of 2002). 
“'average exchange rate' in relation to a year of assessment means-

(a) the average determined by using the closing spot rates at the end of daily, weekly or monthly intervals during that year of assessment; or

(b) the weighted average determined by using the closing spot rates at the end of daily, weekly or monthly intervals during that year of assessment, during which income is received or accrued or expenditure is incurred, which average must be based on-

(i) the net amount of receipts and accruals (excluding those of a capital nature) and deductible expenditure during each such period; and

(ii) the net amount of capital gains or capital losses determined in respect of any disposal of assets during that period,

which must be consistently applied within that year of assessment;”

The average exchange rate for the year of assessment might be calculated to be the same as the spot rate in a company with a small number of foreign exchange transactions, but in larger companies with numerous foreign exchange transactions the average exchange rate could differ substantially from the spot rate on the day of the transaction. This can be illustrated by means of the following:

\section{Example}

A taxpayer (with a February year end) sold trading stock for \$3 000 on 28 November 2003 when the spot rate was $\$ 1=\mathrm{R} 6.369$. This was the only transaction in foreign currency during the year of assessment.

When calculating the average exchange rate the taxpayer will have the choice of calculating the average exchange rate by using the closing spot rates at the end of daily, weekly or monthly intervals during the applicable tax year, or a weighted average (as per the definition of "average exchange rate" in section 1 of the Act). Average exchange rate for the taxpayer in the example will therefore be either:

- $\quad \$ 1=\mathrm{R} 7.284$, if the taxpayer decides on using the closing spot rates at the end of monthly intervals; or

- $1 \$=$ R6.369, if the taxpayer calculates the average exchange rate using the net amount of receipts, accruals and deductible expenditure in each such period and the net amount of capital gains or capital losses determined in respect of any disposal of assets during the year. Since the \$3000 sale was the only transaction in foreign currency for the year of assessment, the average exchange rate will equal the spot rate on the day: 
Implications of the calculation of the average exchange rate and the view of the South African Revenue Service

The calculation of the average exchange rate can vary greatly from taxpayer to taxpayer depending on the chosen method of calculation. The calculation of the average exchange rate might also be a time-consuming exercise, especially if the closing spot rates at daily intervals are selected as the preferred method of calculation.

In other countries (for example Australia), the tax authority publishes the average exchange rates to assist taxpayers in translating foreign income into Australian dollars.

According to paragraph 12 of the press release from the Minister for Revenue in Australia, average exchange rates for selected countries are now available from Branches of the Australian Taxation Office (Minister for Revenue \& the Assistant Treasurer 2002:accessed 6 June 2003).

At present the average exchange rate is not available on SARS's website (www.sars.gov.za: accessed 7 April 2004). On SARS's website there is a link to the website of the South African Reserve Bank (www.reservebank.co.za: accessed 7 April 2004). On the home page of the South African Reserve Bank the Rand/Dollar, Rand/Pound and Rand/Euro exchange rates of the current day appear. When a search is performed on the average exchange rate it appears that neither of these websites currently provides the average exchange rates. On the website www.X-rates.com (accessed 7 April 2004) the monthly average exchange rate of the South African Rand against various currencies, can be obtained. It is hoped that SARS will follow the Australian example, and publish the average exchange rates to assist taxpayers in their translation of foreign currency transactions.

One of the first questions asked when calculating the average exchange rate, is whether one should use the selling or buying rate in the calculation. Currently, no mention is made in either legislation or Explanatory Memoranda. The definition of "average exchange rate" in section 1 of the Act merely refers to the closing spot rate at the end of daily, weekly or monthly intervals. From discussions with SARS officials the telegraphic transfer buying rates released by the South African Reserve Bank is the rate to be used in calculating the average exchange rate.

This follows the method set out in the Australian press release which states "the daily telegraphic transfer buying rates released by the Commonwealth Bank of Australia have been used as the basis for the rates presently available from Branches of the Australian Taxation Office and will be used to compile future rates details” (Minister for Revenue \& the Assistant Treasurer 2002: accessed 6 June 2003). 
In Australia the basis for the calculation of average annual exchange rates is based on the following formula -

$$
\begin{gathered}
((\mathrm{m} 1 * \mathrm{~d} 1)+(\mathrm{m} 2 * \mathrm{~d} 2)+\ldots \ldots+(\mathrm{mi} * \mathrm{di})+\ldots \ldots+(\mathrm{m} 12 * \mathrm{~d} 12)) / \\
(\mathrm{d} 1+\mathrm{d} 2+\ldots \ldots+\mathrm{di}+\ldots \ldots+\mathrm{d} 12)
\end{gathered}
$$

where,

= average exchange rate for month $\mathrm{i}$, being the total of the daily exchange rates released for that month divided by the corresponding number of days (generally there are no rates available on weekends or public holidays). Accordingly, $\mathrm{m} 1, \mathrm{~m} 2$ and $\mathrm{m} 12$ represent the average exchange rates for months 1,2 and 12 respectively

\section{$=$ number of days in month $\mathrm{i}$ for which exchange rates were released}

(Minister for Revenue \& the Assistant Treasurer 2002: accessed 6 June 2003)

In practical terms, this formula represents -

(the sum of all the daily exchange rates released in a year)

/ (the total number of days in the year for which exchange rates were released).

The following example (taken from the press release by the Minister for Revenue $\&$ The Assistant Treasurer 2002:accessed 6 June 2003) illustrates the practical operation of the above-mentioned formula in Australia:

A taxpayer has derived foreign business income from Country $\mathrm{X}$ trading in a fictional currency, South Pacific Pesos, during 1 November 1987 until 31 October 1988. That income has to be translated into Australian dollars at the average annual exchange rate applicable. To arrive at that average exchange rate, the taxpayer will be able to obtain the following exchange rate information from a Branch of the Australian Taxation Office: 
Country X (1 November 1987 - 31 October 1988)

\begin{tabular}{l|c|c|c}
\hline \multicolumn{1}{c|}{ Month } & $\begin{array}{c}\text { Monthly Average } \\
\text { (mi) (South } \\
\text { Pacific Pesos) }\end{array}$ & $\begin{array}{c}\text { Number of Days } \\
\text { Quoted (di) }\end{array}$ & $\begin{array}{c}\text { Monthly Sales } \\
\text { ('000) }\end{array}$ \\
\hline November & 941 & 22 & 40 \\
\hline December & 873 & 20 & 50 \\
\hline January & 879 & 22 & 40 \\
\hline February & 888 & 22 & 30 \\
\hline March & 907 & 20 & 5 \\
\hline April & 915 & 21 & 2 \\
\hline May & 875 & 20 & 7 \\
\hline June & 870 & 20 & 12 \\
\hline July & 900 & 22 & 10 \\
\hline August & 923 & 20 & 8 \\
\hline September & 925 & 21 & 10 \\
\hline October & 948 & 21 & \\
\hline & & & \\
\hline
\end{tabular}

The average exchange rate will be calculated accordingly -

$[(941 * 22)+(873 * 20)+(879 * 22)+(888 * 22)+(907 * 20)+(915 * 21)+(875$ $* 20)+(870 * 20)+(900 * 22)+(923 * 20)+(925 * 21)+(948 * 21)] /$

$[(22+20+22+22+20+21+20+20+22+20+21+21)]$

ie: $226884 / 251=904$

In Australia the average yearly or part-yearly (where a business commences or ceases during a month) exchange rate basis is to be applied as a general rule. However, where a taxpayer carries on business for the whole or a part of a year, but business transactions are mainly concentrated during a part of the relevant period, the use of a yearly or part-yearly average exchange rate to translate income could produce unwarranted distortions. Accordingly, where a taxpayer can demonstrate that those distortions would be significant, the taxpayer may be permitted to use (for that year of income) an average exchange rate that more appropriately reflects the taxpayer's activities. The taxpayer must provide full details in the relevant return of income. The information provided would need to be sufficient to demonstrate that no unwarranted tax advantage is being sought by adoption of that method of currency translation for the year of income concerned in lieu of the general average rate basis. The taxpayer would be required to use the same basis of currency translation from year to year unless it can be demonstrated that circumstances peculiar to the one income year warrant a "one-off" departure from the general average rate basis. (Minister for Revenue \& the Assistant Treasurer 2002:accessed 6 June 2003).

For example, the use of an average monthly exchange rate weighted by the gross sales of the month would mean that the month with the greatest sales would have the 
greatest bearing on the rate. In the example above, the modified average exchange rate would be 899 .

The average exchange rate will be calculated accordingly -

$[(941 * 40)+(873 * 50)+(879 * 40)+(888 * 30)+(907 * 5)+(915 * 2)+(875 *$ $5)+(870 * 7)+(900 * 12)+(923 * 10)+(925 * 8)+(948 * 10)] /$

$[(40+50+40+30+5+2+5+7+12+10+8+10)]$

ie: $196830 / 219=899$

Another important alternative, specified in the press release (Minister for Revenue \& The Assistant Treasurer 2002: accessed 6 June 2003), is the option that the taxpayer may be permitted in certain circumstances to translate at the rates of exchange, which prevailed on the dates on which the transactions took place. These circumstances will again be if the taxpayer can demonstrate that business transactions are mainly concentrated during a part of a year. Again the taxpayer must provide full details in the relevant return of income.

From the above it is clear that there are more precise guidelines on how the average exchange rate should be calculated in Australia, than is currently the situation in the Republic. The average exchange rate in Australia is calculated on daily exchange rates and only if a taxpayer can demonstrate that the business transactions are mainly concentrated during a part of the relevant year, may the taxpayer be permitted to use an average exchange rate that more appropriately reflects the taxpayer's activities.

At present a taxpayer in the Republic will be entitled to choose the calculation method that will be the most beneficial to the taxpayer. Some will use the closing spot rate at the end of daily intervals and others on weekly or monthly intervals. Some taxpayers may use the weighted average method.

In discussions with SARS it was mentioned that they are busy writing an Interpretation Note on section 25D. This Interpretation Note will only be available later in 2004.

\section{SECTION 24I(11)}

\section{Scope}

In order to illustrate the effect of the legislation contained in section 24I(11), it is necessary to first discuss the scope of section 24I. Section 24I of the Act previously applied to all companies (therefore also to close corporations), trusts carrying on any trade and natural persons holding any exchange item for purposes of trade. An $\underline{\text { exchange item held for purposes of trade would therefore taint all other exchange }}$ 
items held by that natural person and section 24I will apply to all exchange items held by that person (Department of Finance, Explanatory Memorandum 2002:1415).

Act 74 of 2002 has limited the scope of this section for years of assessment commencing on or after 13 December 2002, specifically as far as natural persons are concerned. Section 24I(2) has been amended to apply only in respect of natural persons who hold a unit of currency or a loan, advance or debt 'as trading stock' as opposed to the previous requirement 'for purposes of trade'. Furthermore this section will now also apply to any trust or natural person in respect of any forward exchange contract or foreign currency option contract (whether held for trade or as trading stock or not). The scope of section 24I can be illustrated schematically as follows:

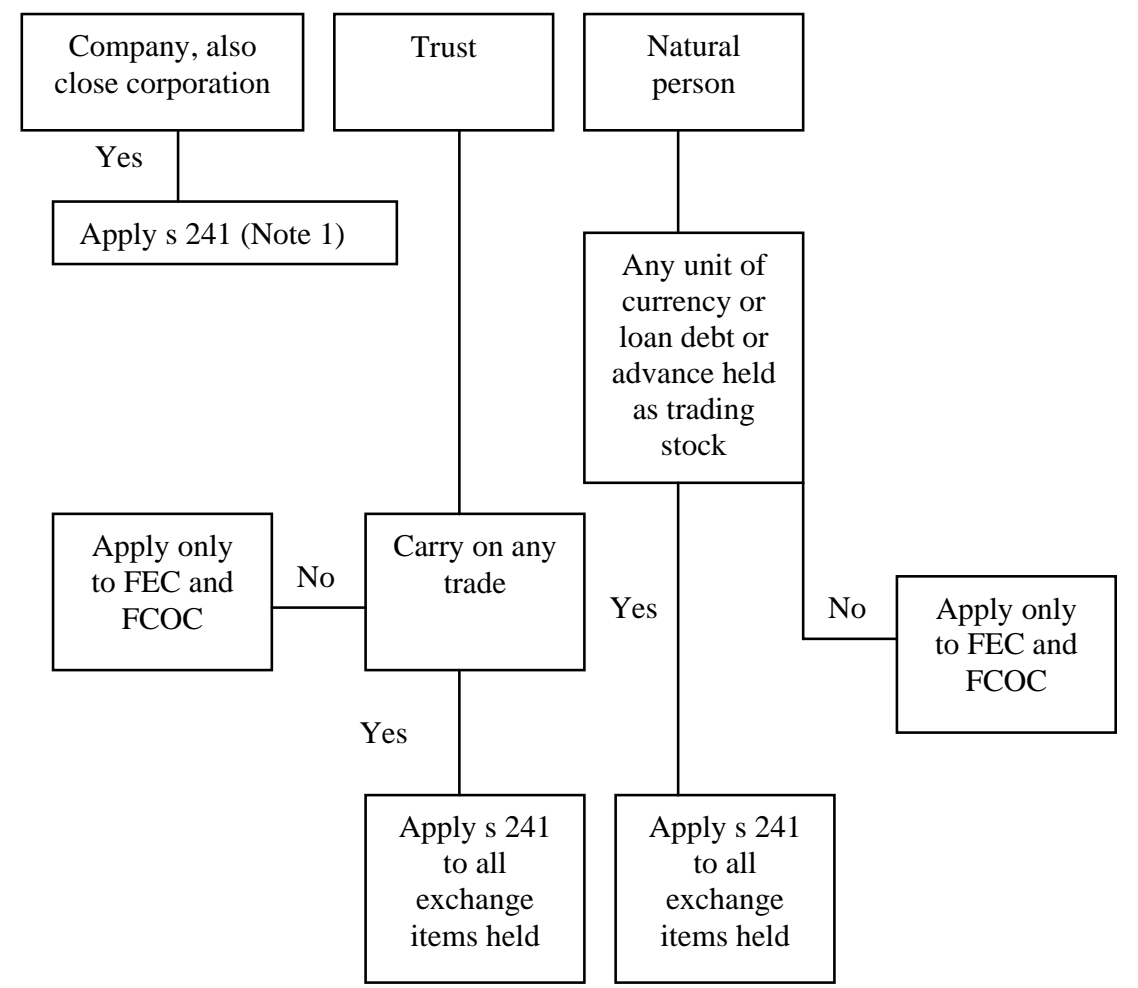

Note 1: Although all exchange items of a company are treated in terms of section 24I, note that if the provisions of section 24I(11) as amended by Act 45 of 2003 (a detailed discussion follow later) apply to a company, the transaction will be treated in terms of the Eighth Schedule. 
The legislation contained in section 24I(11) and the effect on taxpayers over the past two years, as well as the confusion caused by it, can best be illustrated by first discussing the amendments (contained in Act 74 of 2002 and Act 45 of 2003) and then comparing the difference in application in two examples.

\section{Changes relating to section 24I(11) contained in Act 74 of 2002}

Before the amendments contained in Act 74 of 2002, section 24I(11) provided that no amount should be included in income or be deducted from income in terms of section 24I, in respect of any exchange difference arising from a loan, advance or debt incurred by a taxpayer to acquire an asset to which the provisions of paragraph 43(1) or (2) of the Eighth Schedule applied, as well as the exchange differences on the accompanying FEC or FCOC (Arendse, Jordaan, Kolitz \& Stein 2003:441). Paragraph 43(1) stated that the exchange differences during ownership of an asset, for which expenditure was incurred in a foreign currency and which was then sold in the same foreign currency, should not be recognised in that the proceeds and base cost were to be translated to the currency of the Republic, at the spot rate on the date of disposal. Paragraph 43(2) referred to an asset purchased in one currency and disposed of in another currency. It stated that the capital profit or loss should be calculated by translating the proceeds and the base cost on date of disposal to the currency of expenditure. The capital profit or loss should then be translated to the currency of the Republic by applying the rules of Part XIII of the Eighth Schedule (which dealt with foreign currency transactions and has also been amended by Act 74 of 2002)(Arendse et al 2003:605).

With the amendments implemented by Act 74 of 2002, section 24I(11) reads as follows:

“(11) No amount shall be included in or deducted from the income of a person in terms of this section in respect of any exchange differences arising from-

(a) Any amount owing by a person in respect of a loan, advance or debt incurred by that person in foreign currency to acquire any asset, other than an asset-

(i) which constitutes an exchange item;

(ii) the currency of expenditure of which is denominated in the local currency of that person; or

(iii) in respect of which the provisions of section 9G or paragraph 43(4) of the Eighth Schedule applies; and

(b) Any forward exchange contract or foreign currency option contract entered into to hedge such loan, advance or debt.” 
The changes to this section are effective for years of assessment starting on or after 13 December 2002.

\section{Implications of the changes in legislation}

After these amendments the section provided that no amount must be included in or deducted from income in terms of section 24I in respect of any realised and unrealised gains and losses (on the loan, advance or debt, as well as the FEC or FCOC, if applicable) if a loan was raised in a foreign currency to obtain any asset, other than:

- $\quad$ An asset acquired in the local currency of the taxpayer;

- $\quad$ An exchange item (e.g. loan, advance, unit of currency);

- A foreign equity instrument (in respect of which section 9G applies); or

- Real estate or other interests or rights in real estate, irrespective of whether the property is owned by a resident or non-resident and assets, other than real estate, of a non-resident that is attributable to a permanent establishment situated in the Republic. Specifically excluded from these assets is an amount in foreign currency owing to a person in respect of any loan, advance or debt payable to the taxpayer (para 43(4) of the Eighth Schedule) (2003 SAICA Tax Refresher Seminar:84-85).

It is the view of Huxham and Haupt (Tax Amendments Seminar 2003:32) that this amendment does not seem to make sense because the effect appears to be to exclude from the provisions of section 24I any gains or losses arising on the acquisition of any asset (other than the ones specifically excluded). In effect it seems to negate the provisions of section 24I almost completely if a foreign asset is purchased.

Section 24I(11) implied that exchange differences on all assets (except for the exclusions), if financed when purchased in a foreign currency, will not be allowed. As this section did not specifically exclude the purchase of stock or merchandise (although certain interpretations of this amendment implied as much (Clegg \& Stretch 2003:32)), the exchange differences on these transactions, had to be excluded from income tax calculations. An example will best illustrate the effect. Before an example can be used, the changes contained in Act 45 of 2003 and the interaction between section 24I (foreign exchange), section 25D (determination of taxable income in foreign currency) and the Eighth Schedule (which contains the Capital Gains Tax provisions) needs to be illustrated. 
No explanation is provided by SARS in the Explanatory Memorandum 2002 regarding the changes to section 24I(11) contained in Act 74 of 2002.

In the 2003 Budget Tax Proposals (Department of Finance 2003:30) it seems as if SARS is aware of the problem, specifically relating to stock, as a result of the amendments contained in Act 74 of 2002. Under miscellaneous amendments to the Income Tax Act they list the following:

"Provide parity for indebted importers in respect of foreign currency exchange differences: Under current law, an importer borrowing foreign funds to acquire merchandise for sale within SA is subject to inconsistent foreign currency treatment. The currency exchange differences on the borrowed funds are disregarded while the profit (including any currency gain) on the merchandise is fully taken into account. This unintended consequence of the 2002 tax legislation will be corrected.”

\section{Changes relating to section 24I(11) contained in Act 45 of 2003}

As promised by SARS in the 2003 Budget Tax Proposals, the exclusion of exchange differences on the exchange item relating to merchandise (trading stock) purchased in a foreign currency, from a taxpayer's taxable income, was rectified retrospectively with effect from years of assessment commencing on or after 13 December 2002. Making the changes contained in Act 45 of 2003 effective from the same date as the changes contained in Act 74 of 2002 is as good as an admission that (once again) the implications of legislation published was not properly thought through.

The changes to section 24I(11) contained in Act 45 of 2003 is underlined in the abstract from the Act:

“(11) No amount shall be included in or deducted from the income of a person in terms of this section in respect of any exchange differences arising from-

(a) Any amount owing by a person in respect of a loan, advance or debt incurred by that person in foreign currency to acquire any asset, other than an asset-

(i) which constitutes an exchange item;

(ii) the currency of expenditure of which is denominated in the local currency of that person; or

(iii) in respect of which the provisions of section 9G or paragraph 43(4) of the Eighth Schedule would apply had that asset been disposed 
(b) Any forward exchange contract or foreign currency option contract entered into to hedge such loan, advance or debt.”

\section{Implications of the changes in legislation}

The Explanatory Memorandum 2003 (Department of Finance:61) gives background to this amendment as follows:

"Under current law, South African borrowers of foreign currency debt are taxed on an annual basis on currency gains economically arising in respect to that debt. Currency gains and losses associated with South African inventory imported to the Republic are ignored, even if the currency gains and losses arise with respect to those imports. This anomaly is corrected in respect of foreign currency debts associated with assets which are deemed to be a South African sourced asset (capital assets as well as trading stock). This amendment should be read with the amendment to paragraph 43(4) of the Eighth Schedule to the Income Tax Act. In essence, exchange gains and losses attributable to any asset will not be disallowed in terms of section 24I(11) where the provisions of section 9G or paragraph 43(4) of the Eighth Schedule would apply had that asset been disposed of regardless of whether or not that asset constitutes trading stock.”

Drawn from this extract from the Explanatory Memorandum 2003, the provisions of section 24I(11) (as amended by Act 45 of 2003) have changed as follows:

- The provisions of section 24I(11) will now also not apply to any asset of a resident, except assets attributable to a permanent establishment situated outside the Republic. This inclusion is a direct result of the changes contained in Act 45 of 2003 to paragraph 43(4) of the Eighth Schedule.

- $\quad$ Section 24I(11) now specifically states that assets, irrespective of whether these assets are trading stock, to which the provisions of section 9G (financial equity instruments) and paragraph 43(4) of the Eighth Schedule would apply should they be disposed of, should also be excluded from the provisions of section 24I(11). This results in the exchange differences on the exchange item when trading stock items are purchased with a loan raised in a foreign currency, to once again (after being excluded by the provisions of section 24I(11) as amended by Act 74 of 2002) be included in the scope of section 24I.

The above interpretation appears to also be the acceptable interpretation followed by practitioners (KPMG 2004:1-2). 
Therefore section 24I(11) now provides that no amount must be included in income or be deducted from income in terms of section 24I in respect of any realised and unrealised gains and losses (on the loan, advance or debt, as well as the FEC or FCOC, if applicable) if a loan was raised in a foreign currency to obtain:

- $\quad$ real estate situated outside the Republic;

- an amount in foreign currency owing to a person in respect of any loan, advance or debt payable to the taxpayer;

- $\quad$ assets of a permanent establishment of a resident outside the Republic; and

- movable assets of a non-resident not attributable to a permanent establishment in the Republic.

Based on this interpretation it appears that most of the discrepancies regarding the interpretation of section 24I(11) have been removed. The one anomaly that remains is the fact that the date on which the amendments contained in Act 45 of 2003 comes into operation differ for section 24I(11) and paragraph 43(4) of the Eighth Schedule. For section 24I(11) it is effective for years of assessment commencing on or after 13 December 2002 and paragraph 43(4) came into operation for disposals on or after the date of promulgation of the Act (22 December 2003). Theoretically this could imply that paragraph 43(4), as amended by Act 74 of 2002, should be referred to until the effective date of the amended paragraph on 22 December 2003, which would imply that section 24I(11) could be applicable to any asset of a resident, except assets attributable to a permanent establishment situated outside the Republic, until 21 December 2003. We are however of the opinion that this could not have been the intention, specifically since the Explanatory Memorandum 2003 (Department of Finance:61) specifically states that the amendment to section 24I(11) should be read in conjunction with the amendment to paragraph 43(4) contained in Act 45 of 2003.

\section{Section 24I, section 25D and the Eighth Schedule}

This interaction will be discussed based on the amendments contained in Act 45 of 2003, promulgated on 22 December 2003. A detailed discussion of the Eighth Schedule falls outside the scope of this paper and therefore only the applicable paragraphs will be discussed briefly.

It should be noted that every foreign currency transaction has two legs, namely the underlying asset (non-monetary item) and the foreign currency liability (exchange (monetary) item). Each of these will have to be investigated. 


\section{Import of an asset}

The following table illustrates the interaction between sections 24I, 25D and the Eighth Schedule if an item was imported and financed with a loan raised in a foreign currency.

\begin{tabular}{|l|l|}
\cline { 2 - 3 } \multicolumn{1}{c|}{ Underlying asset purchased in foreign currency } \\
\cline { 2 - 3 } \multicolumn{1}{c|}{ Stock } & \\
\hline $\begin{array}{l}\text { Section 25D applies (recorded } \\
\text { at average exchange rate) }\end{array}$ & $\begin{array}{l}\text { Section 25D applies (recorded at } \\
\text { average exchange rate) and } \\
\text { para 43 (refer Note 1) of the } \\
\text { Eighth Schedule will be applicable } \\
\text { to the asset. }\end{array}$ \\
\hline
\end{tabular}

Foreign currency liability (exchange item)

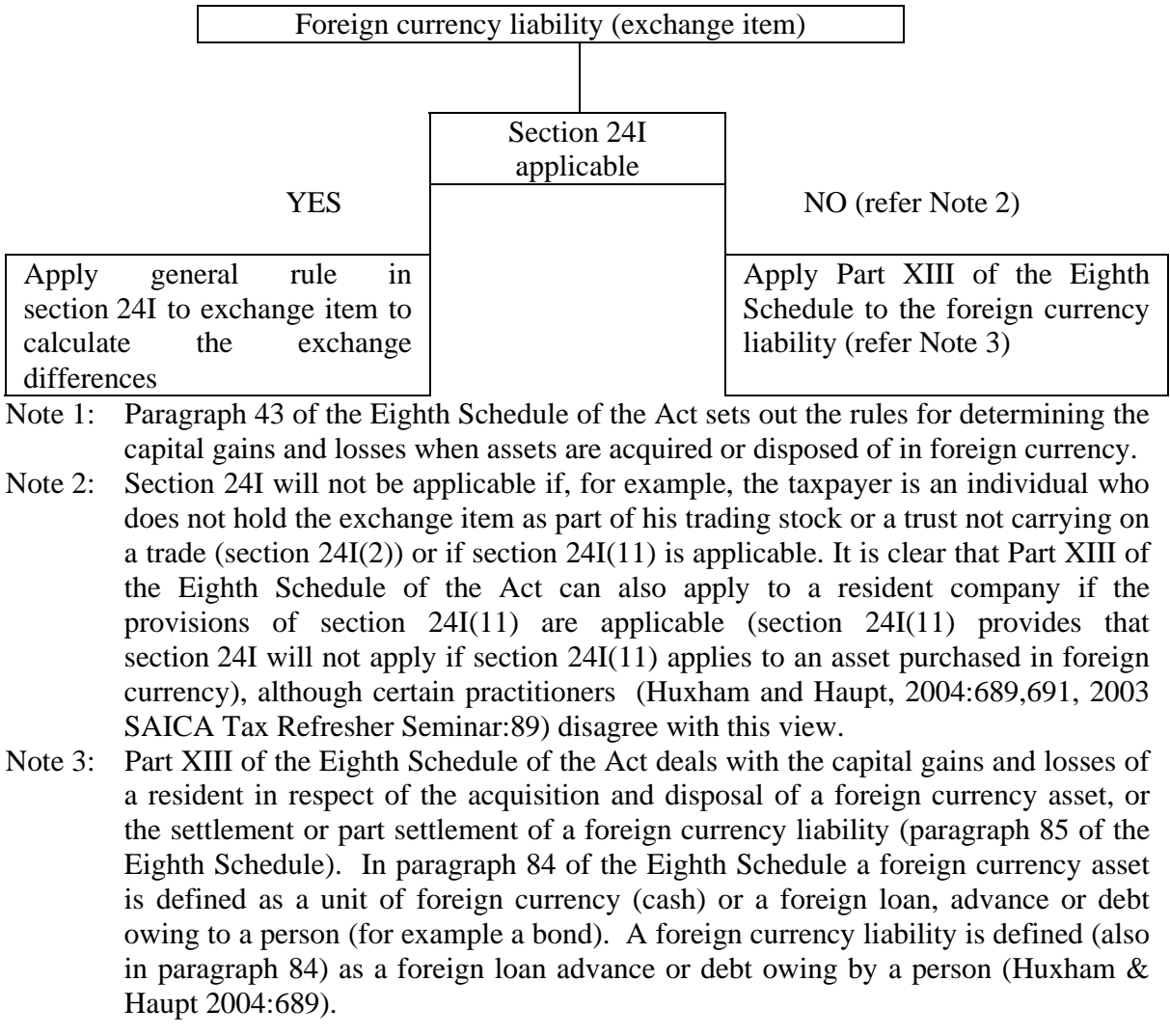




\section{Import of a service}

If a service was imported, the service would be recorded at the average exchange rate (section 25D) and section 24I will apply to the liability (exchange item). If section 24I is not applicable, Part XIII of the Eighth Schedule will apply. Note that section 24I(11) cannot apply to the liability in this scenario, as section 24I(11) specifically refers to an asset purchased with a loan raised in a foreign currency.

\section{Exports}

The same rules as discussed in the previous two sections will apply to an export, with the only difference being that section 24I(11) will not apply to the exchange item (foreign currency asset) as it is only applicable to assets purchased.

\section{Example: Tax and accounting consequences if stock is purchased in a foreign currency}

The solution to this example reflects both legislation as amended in terms of Act 74 of 2002 and Act 45 of 2003, in order to be able to compare the effect of the amendments of Act 74 of 2002 to the current legislation and to indicate the farreaching effect the ill-considered legislation contained in Act 74 of 2002 would have had on taxpayers.

\section{Example}

FE Limited purchases stock for US\$20 000 from a supplier in the USA on 15 February 2004 (transaction date). The liability is settled on 30 April 2004. The average exchange rate for the year of assessment ending 29 February 2004 was US\$1=R7.284 and for 2005 US\$1=R6.496. The following were the ruling exchange rates:

\section{Date:}

Spot rate

15 February 2004

29 February 2004

30 April 2004

28 February 2005

(US\$1 = R):

6.612

6.625

6.640

6.205

The stock was sold on 28 February 2005 for R180 000. FE Limited has a February year-end. 
The tax and accounting consequences of the above transactions can be illustrated as follows:

\section{4 year of assessment}

\section{Tax consequences:}

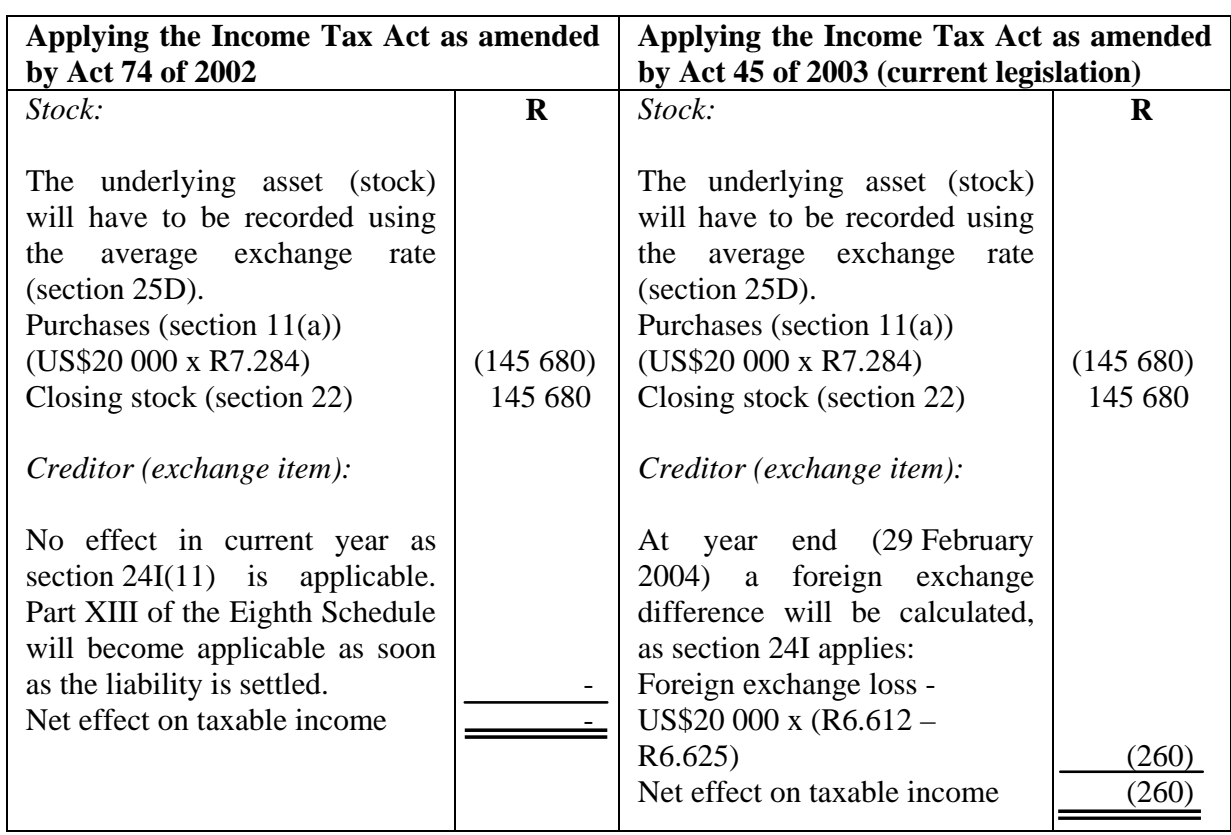

\section{Accounting treatment:}

Stock:

Purchase (US\$20 000 x R6.612)

Closing stock

\section{Creditor:}

Recorded at spot rate on transaction date:

US\$20 000 x R6.612 = R132 240

At year end a foreign exchange difference will be calculated:

Creditor restated at spot at year end (29 February 2004)

US\$20 000 x R6.625 = R132 500

Foreign exchange loss of R260 for accounting (R132 240 - R132 500) 
2005 year of assessment:

Tax consequences:

\begin{tabular}{|c|c|c|c|}
\hline \multicolumn{2}{|c|}{$\begin{array}{l}\text { Applying the Income Tax Act as amended } \\
\text { by Act } 74 \text { of } 2002\end{array}$} & \multicolumn{2}{|c|}{$\begin{array}{l}\text { Applying the Income Tax Act as amended } \\
\text { by Act } 45 \text { of } 2003 \text { (current legislation) }\end{array}$} \\
\hline $\begin{array}{l}\text { Stock: } \\
\text { The underlying asset (stock) } \\
\text { will have to be recorded using } \\
\text { the average exchange rate } \\
\text { (section 25D). } \\
\text { Opening stock (section 22) } \\
\text { Sales } \\
\text { Creditor (exchange item): } \\
\text { Part XIII of the Eighth } \\
\text { Schedule (specifically } \\
\text { paragraph 93) will become } \\
\text { applicable to the foreign } \\
\text { currency liability as soon as the } \\
\text { liability is settled on } 30 \text { April } \\
2004 \text {. Paragraph } 93 \text { states that if } \\
\text { the gain or loss arises out of the } \\
\text { settlement or part settlement of } \\
\text { a foreign currency liability, it } \\
\text { will be calculated as follows: } \\
\text { Debt translated to Rand at the } \\
\text { average exchange rate for the } \\
\text { year of assessment during } \\
\text { which it was incurred } \\
\text { Less: Same debt translated to } \\
\text { Rand at the average exchange } \\
\text { rate for the year of assessment } \\
\text { during which it is settled } \\
\text { If applied to the example, the } \\
\text { result will be as follows: } \\
\text { Debt incurred } \\
\text { (US } \$ 20000 x \text { R7.284) } \\
\text { Less: Debt settled on } 30 \text { April } \\
2004 \text { (US } \$ 20000 \times \text { R6.496) } \\
=\text { (R145 } 680 \text { - R129 920) } \\
=\text { R15 } 760 \text { capital gain } \\
x \text { Inclusion rate of } 50 \% \text { (since } \\
\text { FE Limited is a company) } \\
\text { Net effect on taxable income }\end{array}$ & $\begin{array}{r}(145680) \\
180000 \\
34320\end{array}$ & $\begin{array}{l}\text { Stock: } \\
\text { The underlying asset (stock) } \\
\text { will have to be recorded using } \\
\text { the average exchange rate } \\
\text { (section 25D). } \\
\text { Opening stock (section 22) } \\
\text { Sales } \\
\text { Creditor (exchange item): } \\
\text { On settlement of the debt } \\
\text { (30 April 2004) a foreign } \\
\text { exchange difference will be } \\
\text { calculated, as section 24I } \\
\text { applies: } \\
\text { Foreign exchange loss - } \\
\text { US\$20 } 000 \times \text { (R6.625 - 6.640) } \\
\text { Net effect on taxable income }\end{array}$ & $\begin{array}{r}(145680) \\
180000 \\
34320\end{array}$ \\
\hline
\end{tabular}

R Oberholzer \& JS Wilcocks 


\section{Accounting treatment:}

Stock:

\section{Creditor:}

Creditor paid at spot rate on 30 April 2004:

US\$20 000 x R6.640 = R132 800

Foreign exchange loss made on payment of R300 (R132 500 - R132 800).

\section{Conclusions from the above example}

Differences between the accounting treatment and the tax treatment according to the Income Tax Act as amended by Act 74 of 2002:

- Note that the taxation and the accounting treatment of foreign exchange transactions were the same before the amendments contained in Act 74 of 2002 were promulgated.

- $\quad$ There is a difference of R13 440 (R47 760 - R34 320) between the accounting and tax profit on the stock sold, due to the application of section 25D. This is the result of the different rates used to record the asset for accounting (R132 240 (translated at spot rate)) versus taxation (R145 680 (translated at the average exchange rate)). This difference will lead to temporary differences for accounting purposes.

- $\quad$ For tax purposes a taxable capital gain of R7 880 is made on the creditor. The net effect for accounting purposes due to foreign exchange differences is a R560 loss (R300 (loss) plus R260 (loss)). The difference is due to the application of section 24I(11) (as amended by Act 74 of 2002) and the resultant application of the Eighth Schedule. This difference will lead to temporary differences for accounting purposes.

- The actual cash outflow on purchasing the stock is R132 800 (before taking into account tax payable at 30\%). This R132 800 is the US\$20 000 translated to Rand on the date of settlement of the debt by using spot rate (R6.640) on 30 April 2004. The net effect of the purchase for accounting purposes reflects this cash flow effect, therefore R132 800 deducted from net profit over the twoyear period. The net deduction of R132 800 consists of the purchase price of R132 240 (a deduction) of the trading stock and the net foreign exchange loss of R560 (R300 (loss) plus R260 (loss)). For tax purposes the net effect of the purchase of the stock is a deduction of R137 800. This R137 800 deduction consists of the purchase price of the stock of US\$20 000 translated at the 
average exchange rate for the 2004 year of assessment of R7.284, resulting in a deduction of R145 680 and the taxable capital gain of R7 880 on the exchange item. Although there is only a cash outflow of R132 800, an amount of R137 800 will be deductible before tax at the rate of $30 \%$ is calculated. This difference is due to the use of the average exchange rate in terms of section 25D to translate the purchase price of the trading stock and the use of the Eighth Schedule (which only includes 50\% of the profit) to account for the settlement of the exchange item (where the average exchange rate is also used to translate the liability on date incurred and on date settled).

Differences between the accounting treatment and the tax treatment according to the Income Tax Act as amended by Act 45 of 2003 (current legislation):

- The difference on the profit made on the stock sold of R13 440, due to the application of the provisions of section $25 \mathrm{D}$, remains unchanged. This will therefore still result in temporary differences for accounting purposes.

- The amendments to section 24I, and specifically 24I(11), read in conjunction with paragraph 43(4) of the Eighth Schedule of the Act, results in the taxation and the accounting treatment of the exchange item to once again be the same for (most) foreign exchange transactions. There are therefore no longe temporary differences on the treatment of the exchange item for accounting purposes.

- $\quad$ The actual cash outflow on purchasing the stock as well as the amount deducted from profit for accounting purposes amounts to R132 800 (before taking into account tax payable at 30\%). For tax purposes the net effect of the purchase of the stock is a deduction of R146 240. This R146 240 deduction consists of the purchase price of the stock of US\$20 000 translated at the average exchange rate for the 2004 year of assessment of R7.284, resulting in a deduction of R145 680 and the net foreign exchange loss of R560 (R300 (loss) plus R260 (loss)). Although there is only a cash outflow of R132 800, an amount of R145 680 will be deductible before tax at the rate of $30 \%$ is calculated. The difference is due to the use of the average exchange rate in terms of section 25D to translate the purchase price of the trading stock.

Difference in tax treatment according to the Income Tax Act as amended by Act 74 of 2002 and the Income Tax Act as amended by Act 45 of 2003:

- $\quad$ The application of section 25D remains unchanged.

- In terms of the legislation as amended until Act 74 of 2002, a taxable capital gain of R7 880 was made on the creditor. In terms of the current legislation (as amended by Act 45 of 2003) a foreign exchange loss of R560 (R300 (loss) plus 
R260 (loss)) is made on the creditor. The difference relates to the application of section 24I and not the Eighth Schedule.

- $\quad$ The foreign currency difference calculated on the exchange item (the creditor) in terms of section 24I (as amended by Act 45 of 2003) reflects the actual difference due to currency fluctuation between the initial recorded amount on date of purchase and the actual settlement amount.

\section{Example: Tax and accounting consequences if a fixed asset is} purchased in a foreign currency

If the same information is used as in the previous example, but a fixed asset and not stock is purchased, the tax and accounting consequences will be as follows: (Assume that in order to keep the example as simple as possible, no wear-and tear or depreciation is written-off on the asset and that only the current legislation (as amended by Act 45 of 2003) is taken into account for tax purposes).

\section{4 year of assessment:}

\section{Tax consequences:}

Asset:

No tax effect in the 2004 year of assessment, as it is a capital asset, but the asset will be recorded at the average exchange rate in terms of section 25D (US\$20 $000 \mathrm{x}$ R7.284 = R145 680) for recording purposes and to calculate future tax implications.

Creditor (exchange item):

At year end (29 February 2004) a foreign exchange difference will be calculated, as section 24I applies:

Foreign exchange loss: US\$20 000 x (R6.612 - 6.625)

Net effect on taxable income

\section{Accounting treatment:}

Asset:

Recorded at spot rate R132 240 (US\$20 000 x R6.612) for accounting purposes

Creditor:

Recorded at spot rate on transaction date:

US\$20 000 x R6.612 = R132 240

At year end a foreign exchange difference will be calculated:

Creditor restated at spot at year end (29 February 2004)

US\$20 000 x R6.625 = R132 500

Foreign currency loss of R260 for accounting (R132 240 - R132 500) 
2005 year of assessment:

\section{Tax consequences:}

Asset:

Paragraph 43 and specifically paragraph 43(4) of the Eighth Schedule will become applicable to the asset on the date of disposal. Paragraph 43(4) states that if the asset was acquired or disposed of in a currency other than the currency of the Republic, the capital gain or loss on disposal must be calculated by first translating the proceeds into the currency of the Republic at the average exchange rate (in our example this will not be necessary as the proceeds is in Rand) and the allowable expenditure in terms of paragraph 20 (base cost) into the local currency at the average exchange rate for the year of assessment during which the expenditure was incurred. If this is applied to the example, the effect will be as follows:

Proceeds

$\mathbf{R}$

180000

Base cost (para 43(4)) (US\$20 000 x R7.284)

(145 680)

Capital gain

34320

$\mathrm{x}$ Inclusion rate of $50 \%$ (since FE Limited is a company)

$\mathbf{R}$

Creditor (exchange item):

On settlement of the debt (30 April 2004) a foreign exchange

difference will be calculated, as section 24I applies:

Foreign exchange loss - US\$20 000 x (R6.625 - R6.640)

Net effect on taxable income

\section{Accounting treatment:}

Asset:

Cost of asset

Selling price

Accounting profit

Creditor:

Creditor paid at spot rate on 30 April 2004:

US\$20 000 x R6.640 = R132 800

Foreign exchange loss made on payment of R300 (R132 500 - R132 800). 


\section{Conclusions from the above example}

- $\quad$ For tax purposes a taxable capital gain of R17 160 is made on the asset. For accounting purposes a profit of R47 760 is made on the sale of the asset. There is a difference of R30 600 (R47 760 - R17 160) between the accounting and tax profit on the asset sold, due to the application for tax purposes of section 25D and the Eighth Schedule. This difference will lead to temporary differences for accounting purposes.

- The taxation and the accounting treatment of the exchange item will once again be the same for (most) foreign exchange transactions. There are therefore no longer temporary differences on the treatment of the exchange item, as would have been the case if the legislation as amended by Act 74 of 2002 was still applicable.

\section{CONCLUSION}

It is clear from the analysis performed that the treatment of foreign exchange transactions and the legislation regulating it, is a very complex issue. Although the amendments relating to transactions in a foreign currency contained in Act 45 of 2003 clarified some of the matters that resulted from the ill-considered amendments contained in Act 74 of 2002, some unresolved matters still remain. One of the most important unresolved matters is the question of the actual intention of the Legislature relating to the application of the average exchange rate to translate transactions in foreign currency to Rand. Other unresolved matters appear to be the result of illconsidered legislation being passed (for example the inconsistent effective dates of section 24I(11) and paragraph 43(4) of the Eighth Schedule of the Act as amended by Act 45 of 2003). The following is the most important outcome of this study:

- The heading of section 25D refers to "Determination of taxable income in foreign currency" but the words "from a source outside the Republic" were repealed. This section potentially now refers to more than just taxable income from a foreign trade. Based on content analysis it appears that if an amount is received by or accrued to, or an expense is incurred by a taxpayer in a foreign currency, that specific amount must be translated by using the average exchange rate.

- The translation of the purchase price of the underlying asset by using the average exchange rate for tax purposes in terms of section 25D, result in temporary differences for accounting purposes, because the purchase price is recorded at spot rate for accounting. The tax value and the book value will therefore differ from the start.

- If the calculation methods provided to calculate the average exchange rate (in the definition contained in section 1 of the Act) is compared, using the method 
prescribed in part (b) of the definition could result in an average exchange rate that is comparable to spot rate, if it is a company with a low volume of foreign transactions .

- In order to facilitate the whole process of taxpayers accounting for foreign transactions using the average exchange rate in terms of Section 25D, SARS should provide access to updated average exchange rate calculations, as is the case internationally.

- The actual cash flow will not be the same as the net tax effect of a transaction, due to the initial translation of the asset at the average exchange rate. This could be to the advantage of the taxpayer if the average exchange rate is higher than the spot rate on date of purchase, resulting in a greater deduction for tax purposes than the actual amount spent (with the reverse also being true).

- $\quad$ The amendments to section 24I(11), contained in Act 45 of 2003, rectified, with retrospective effect, the unintended exclusion from the taxable income of a resident taxpayer, of the foreign exchange differences on trading stock and other movable assets financed by a loan, advance or debt in a foreign currency. This unintended exclusion was the result of the ill-considered amendments to section 24I(11), contained in Act 74 of 2002.

We expect further changes to legislation regarding foreign exchange transactions, even if only limited to the tidying up of the relevant sections of the Act. The issue of a practical guideline on the treatment of transactions in a foreign currency, with practical examples on topical issues, should be considered by SARS. This could assist to clarify some of the uncertainties experienced by academics and practitioners alike.

\section{REFERENCES}

Arendse, JA, Jordaan, K, Kolitz, MA \& Stein ML. 2003. Silke: South African Income Tax 2003, LexisNexis Butterworths, Durban.

Botha, C. 1998. Statutory Interpretation, An Introduction for Students, Juta \& Co, Ltd, Landsdowne.

Clegg, D \& Stretch, R. 2003. LexisNexis Butterworths - Ernst \& Young. Tax Update Seminar, Pietermaritzburg.

Department of Finance. 2000. Explanatory Memorandum on the Revenue Laws Amendment Bill 2000, Pretoria. 
Department of Finance. 2001. Explanatory Memorandum on the Second Revenue Laws Amendment Bill 2001, Pretoria.

Department of Finance. 2001. Second Revenue Laws Amendment Act (Act 60 of 2001), Pretoria.

Department of Finance. 2002. Explanatory Memorandum on the Revenue Laws Amendment Bill 2002, Pretoria.

Department of Finance. 2002. Revenue Laws Amendment Act (Act 74 of 2002), Pretoria.

Department of Finance. 2003. Explanatory Memorandum on the Revenue Laws Amendment Bill 2003, Pretoria.

Department of Finance. 2003. Revenue Laws Amendment Act (Act 45 of 2003), Pretoria.

Department of Finance. 2003. 2003 Budget Tax Proposals, Pretoria.

Hahlo, H.R. \& Kahn, E. 1973. The South African Legal System and its Background, Juta \& Co, Cape Town.

Huxham, K \& Haupt P. 2003. Hedron Tax Seminars - Tax Amendments Seminar: December 2002 \& Budget 2003 Updates, Hedron Tax Consulting and Publishing CC, Roggebaai.

Huxham, K \& Haupt P. 2004. Notes on South African Income Tax 2004, Twenty third Edition, Hedron Tax Consulting and Publishing CC, Roggebaai. Income Tax Act 58 of 1962.

KPMG. 2004. The taxation of foreign exchange differences - amendment of section 24I(11). KPMG Tax Mail Issue 1/2004. Johannesburg.

Meyerowitz, D. 2002. Meyerowitz on Income Tax, The Taxpayer. Cape Town.

Mitchell, K \& Mitchell, L. 2004. Tax Update - February 2004 BSP Seminars. Mitchell \& Mitchell Tax Service CC. Cape Town.

Minister for Revenue and the Assistant Treasurer Australia - Press release 132/02. 2002. More business tax reform exposure draft legislation, (Online). 


\section{Available:}

(http://law.ato.gov.au/atolaw/view.htm?find=\%22Taxation\%20ruling\%20no.\%20IT \%202498\%22\&docid=ITR/IT2498/NAT/ATO/00001)

Date accessed: 6 June 2003

National Treasury. 2004. Budget Review 2004. Pretoria.

Organisation for Economic Co-operation and Development. 2002. Model Tax Convention on Income and on Capital.

Steyn, LC. 1981. Die uitleg van Wette - 5de uitgawe, Juta, Kaapstad, Wetton, Johannesburg.

The South African Institute of Chartered Accountants - AC 112 - The effects of changes in foreign exchange rates, (Online).

Available:

http://handbook.saica.co.za/saica/lpext.dll?\&f=templates\&fn=altmain-

h.htm\&vid=10.1048\%2Fsaica\&2.0\&lpauthuser $=00038922$

Date accessed: 8 April 2004

The South African Institute of Chartered Accountants - IAS 12 (AC 102) - Income Taxes, (Online).

Available:

http://handbook.saica.co.za/saica/lpext.dll?\&f=templates\&fn=altmain-

h.htm\&vid=10.1048\%2Fsaica\&2.0\&lpauthuser=03092301

Date accessed: 8 April 2004

The South African Institute of Chartered Accountants. 2003. SAICA Tax Refresher Seminar. SAICA. Bruma Lake.

Webster's Revised Unabridged Dictionary, (Online).

Available: http://dictionary.reference.com/search?q=casus\%20omissus

Date accessed: 8 April 2004

\section{COURT CASES}

Stafford v Special Investigating Unit 19984 All SA 543 (E) at 553

Turffontein Estates Ltd v Mining Commissioner, Johannesburg 1917 AD 419 at 431 


\section{ANNEXURE 1}

ABBREVIATIONS USED

Act: The Income Tax Act 58 of 1962 (as amended)

CGT: Capital Gains Tax

FCOC: Foreign currency option contract

FEC: Forward exchange contract

SARS: South African Revenue Services 